Article

\title{
Sustainability in an Emerging Nation: The Bhutan Case Study
}

\author{
Dorji Yangka * (1), Peter Newman (i), Vanessa Rauland and Peter Devereux \\ Curtin University Sustainability Policy (CUSP) Institute, Perth, WA 6160, Australia; \\ p.newman@curtin.edu.au (P.N.); V.Rauland@curtin.edu.au (V.R.); peter.devereux@curtin.edu.au (P.D.) \\ * Correspondence: dorjlhen@gmail.com; Tel.: +61-8-9266-9030; Fax: +61-8-9266-9031
}

Received: 1 April 2018; Accepted: 15 May 2018; Published: 18 May 2018

check for updates

\begin{abstract}
With the onset of the 17 Sustainable Development Goals (SDGs) and the Paris Agreement on climate change, the world's nations were to create economic development integrating environmental and social improvement. However, there is still much uncertainty in the world of politics and academia as to whether these integrated goals are achievable and how they can fit best with diverse national and local contexts. Thus, there is always a need to find nations that can show how it can be achieved in different settings shaped by local experiences, challenges, and opportunities. Bhutan could be one of these nations as it could be argued that it has, to an extent, simplified the task to fit its values and aspirations. Bhutan has three major goals that need to be integrated: Wealth (GDP) to align with their middle-income aspiration, thus providing opportunities for employment, Greenhouse Gas emissions (GHG) that are maintained at a carbon neutral level, which is beyond most national commitments, and Bhutan's renowned Gross National Happiness (GNH) index, which covers their socio-economic goals. We show this integration and then synthesize some core findings from a literature review on the theory and practice of sustainable development through the lens of the three integrated goals of Bhutan, thereby placing the case of Bhutan into the wider literature. This paper seeks to show how one emerging nation can model an operational sustainability policy. The paper highlights some plausible synergies between the 17 SDGs and the domains and indicators of GNH that could help nations struggling with how they can create sensible sustainability outcomes from these new global agendas. Bhutan has framed the GNH as its contribution to sustainability. However, this paper suggests that it may be the integration of the GNH with GDP and GHG that is its real contribution. Furthermore, Bhutan's 3G model of fully integrating GNH, GDP, and GHG suggests a way forward for achieving their imperatives of economic growth, whilst enabling the SDGs and achieving the difficult climate change goal. It may also suggest a model for other nations wanting to find a complementary way of framing economic growth, the 17 SDGs, and the Paris Agreement into a coherent set of policies.
\end{abstract}

Keywords: Bhutan; sustainable development; Gross National Happiness; well-being; carbon neutral; economic growth; emerging nation; integration; holistic; transition; GHG emissions; environment

\section{Introduction}

In the 1980 's, sustainability became a new global concept that emerged from the inadequacies of single-minded economic development [1]. The conclusion from the UN's World Commission for Environment and Development was that economic growth and development was not the problem in itself, but that environmental and social issues had to be improved in the process and not left to trickle down later. The world's nations were then set on a journey to find new ways of integrating environmental and social impacts into economic development. For the past 30 years, many international conferences and agreements have been helping define the nature of sustainable 
development, from Rio in 1992 to Rio plus 20 [2]. For most of this time, the world has focused on sustainability as the responsibility of the developed world with aid and facilitation of emerging economies to shape their economic development to be more sustainable. This has now changed and the new world of Sustainable Development Goals [3] is making it very clear that the future depends on all nations, including the emerging world, to do economic development sustainably. This paper seeks to show how one emerging nation, Bhutan, is demonstrating how to do sustainable development in their future.

The Sustainable Development Goals (SDGs) have been developed in parallel and integrated into what is perhaps the biggest global environmental issue, climate change. This too began as an agenda for the developed world with the Kyoto Agreement setting out goals for the big polluters and assistance for the emerging world to shape their development more sustainably. However, the Paris Agreement from 2015 is now for every nation to become involved and demonstrate how they can meet the planetary objective of achieving a global economy that keeps emission levels within the $2{ }^{\circ} \mathrm{C}$ rise in global temperature and preferably within $1.5^{\circ} \mathrm{C}$ [4]. This requires Nationally Determined Contributions that can show how every nation can meet their economic goals whilst achieving significant reductions in greenhouse emissions. At the same time, every nation has committed to the SDGs. Thus, there is no room in the agenda for the global future for any nation to say they simply want to create economic development without considering environmental and social improvement. However, there is still much uncertainty in the world of politics and academia that these integrated goals are achievable. Thus, there is always a need to find nations that can show how it can be done. Bhutan could be one of them as it has simplified the case through developing three core goals with each containing measurable indicators. This paper attempts to show how these interconnected goals can enable emerging nations to develop similar approaches to sustainability in the global arena.

Bhutan has three major goals (the three G's) shown in Figure 1 that need to be integrated:

1. Wealth: GDP that can grow to enable them to become a middle-income economy by 2021;

2. Carbon Emissions: GHG that is maintained at a carbon neutral level; and

3. Happiness: Gross National Happiness $(\mathrm{GNH})$ continuing to grow.

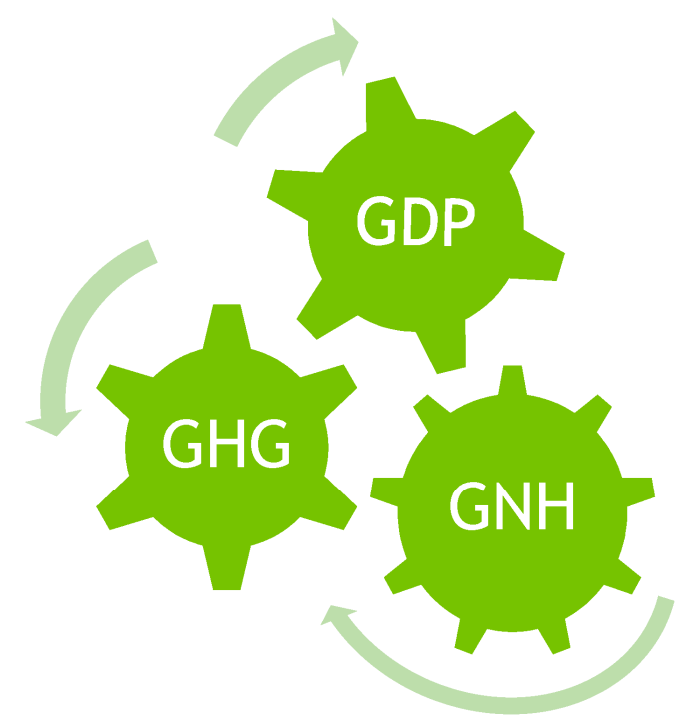

Figure 1. The 3G-the three interconnected goals of Bhutan.

These goals represent Bhutan's contribution to demonstrating sustainability. This paper sets out to show this. To the best of the authors' knowledge, no earlier research had attempted to examine the three G's together especially in the context of the 'sustainability puzzle' [5]. The paper thus is also 
about resolving the conflicts between the three major academic and professional paradigms-economic, environmental and social. The paper seeks to help resolve some of the inherent conflicts between these different areas of thinking and practice.

This paper consists of seven sections with Section 1 providing the background and introduction. Section 2 provides an overview of theories and principles of sustainability and the transition towards sustainability and highlights the confusion being created by disciplinary based approaches to sustainability. Section 3 elaborates on sustainability in Bhutan as viewed through the lens of the three integrated goals and how they relate to the wider literature. Section 4 highlights some grey areas related to Bhutan's socio-economic condition and their development philosophy. Section 5 outlines possible synergies between the 17 SDGs and the domains and indicators of GNH. Section 6 argues carbon neutral development is now a new driver in the global era of Sustainable Development Goals and the Paris Agreement. Finally, the concluding remarks are provided in Section 7.

\section{Sustainability Principles, Theories, and Transitions}

World history since the Brundtland Commission [1] has been about political processes to resolve the inherent conflicts between economic, environmental and social, the three core dimensions of sustainability. Creating sustainable development is the biggest challenge of the $21^{\text {st }}$ century and several practical and academic attempts have been formalized on how to understand and transition towards more sustainable development.

Principles of sustainability have been developed as a means of establishing frameworks for action on sustainability. For example, Newman and Rowe [6] developed ten principles for the Western Australian State Sustainability Strategy (see Figure 2). Generally national strategies used fewer principles and these have been the basis of much of the international dialogue over the meaning of sustainable development [7] such as the four summarized by Quental, Lourenço \& da Silva [8]: the principle of limits, the means and end principle, the needs principle and the complexity principle.

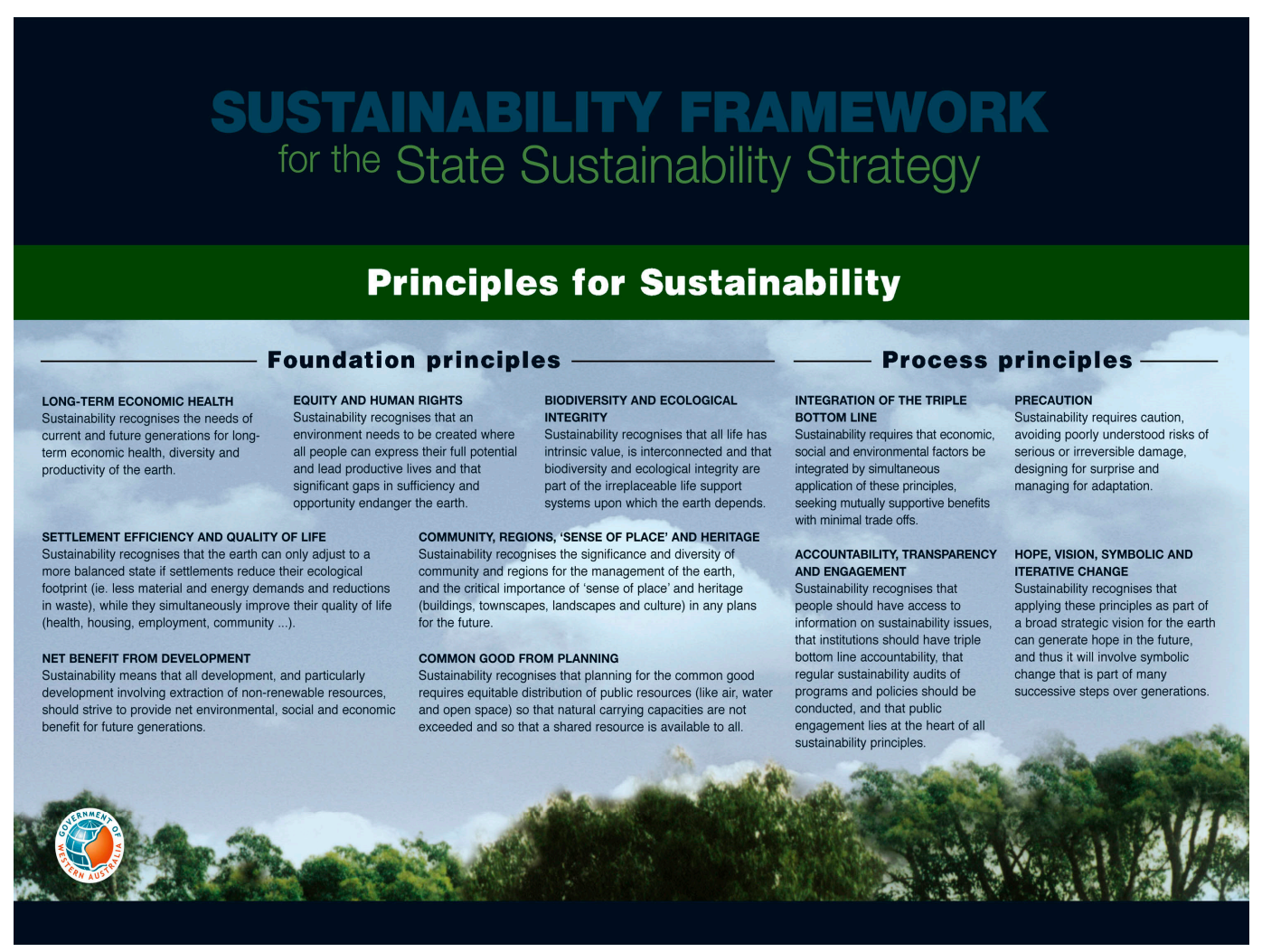

Figure 2. Principles of Sustainability. Source: [6]. 
Quental, Lourenço \& da Silva [8] also conducted a comprehensive synthesis of the sustainability literature to see how the concept was being developed in a more theoretical way. They highlighted three widely accepted scientific approaches to understanding the concept:

1. Ecological Economics,

2. Sustainability Science and

3. Sustainability Transition.

Ecological Economics emphasizes the limits to natural capital $[9,10]$, while Sustainability Science is about the dynamics and vulnerability of the human and nature relationship [11-13]. Sustainability Transition shows how to transition towards sustainability by asking what to sustain and what to develop [14] and generally uses the work of Geels [15,16] on Socio-Technical Transitions and Socio-Ecological Transitions by Ostrom [17], Cumming [18] and Orach and Shulter [19] including the theory of Panarchy [20]. Markard, Raven, and Truffer [21] suggest the Sustainability Transition is a fundamental transformation towards a more sustainable set of socio-economic activities. They recognize that holistic understanding of sustainable development is hampered by different philosophical and ontological assumptions. For instance, the various forms of sustainability assessments are postulated in the literature, which arose out of focusing on separate thematic areas, leading Hacking and Guthrie [22] to propose a methodological framework to compare those various models. Conversely, Halog and Manik [23] proposed an integrated sustainability assessment framework by combining the strengths of those various models.

These disciplines are as complex and puzzling as the complexity of integrating the three core elements of Sustainable Development. In this vein, Cumming [18] rhetorically calls it 'disciplinary snobbishness' that forms a major obstacle to delivering sustainable development. This is a big concern as, despite each of these disparate bodies of knowledge using their own ontology to transition towards sustainable development, the global problem may continue. Given such complexity and seemingly confusing theories and approaches to sustainability, Quental, Lourenço \& da Silva [8] suggest that sustainability is evolving and that it is an 'integrated thesis' towards consilience of various theories and pragmatic approaches that arose from a multitude of disciplinary backgrounds. But then they caution that it remains to be seen whether this 'integrated thesis' is coherent and useful to finding solutions to sustainability in practice. In this vein, Section 3 discusses Bhutan's $3 \mathrm{G}$ model and attempts to explore its possible contribution to the 'integrated thesis'.

\section{Bhutan's Sustainability}

In 1999, while charting its development course to 2020, Bhutan emphasized that the development pathway must be socially, economically, culturally and environmentally sustainable. It was clearly reflected that 'the principle of sustainability must pervade all our thinking on the future development of the Kingdom' [24]. Earlier research by Brooks [25] vividly described sustainability in Bhutan in the framework of the Limits to Growth. The present study outlines sustainability in Bhutan through the lens of its three critical goals.

Bhutan equates its GNH concept (see Section 3.3) as the Bhutanese version of sustainable development [26]. This paper attempts to answer if this hypothesis is true and to what extent it helps to see the interaction of the three G's as a more comprehensive approach that includes the other two powerful goals. The other two G's are GDP and GHG. GDP is discussed below and like most nations the goal is to increase economic opportunities through greater GDP growth. In 2009, during the 15th session of the Conference of Parties, Bhutan pledged to the global community that it will remain carbon neutral in perpetuity $[27,28]$. The pursuit of the GNH philosophy and the hope to remain carbon neutral resonate with the current global sustainable development goals [3] and the climate goal to keep the global temperature rise below $1.5^{\circ} \mathrm{C}$, which inevitably requires net zero carbon emissions [29]. To achieve such desirable yet challenging tasks, Newton and Newman [30] reflect that normative goals such as restoring environmental quality, improving human well-being, efficient use of 
resources, emissions reduction, and others should be addressed through a sustainability transition. How such issues are being addressed in Bhutan under its three interconnected goals are discussed in the following subsections.

\subsection{Gross Domestic Product}

The economy of Bhutan has undergone significant structural changes over the last decades. In other words, the contribution to GDP by the three major economic activities such as primary, secondary and the tertiary sectors have changed significantly. For instance, the contribution of the primary sector (comprising of agriculture, forestry, and mining) to the stacking of GDP decreased from $56 \%$ in 1980 to $27 \%$ in 2003 [31] and eventually declined to $16.5 \%$ in 2016 [32]. Conversely, the secondary sector which comprises the energy, construction, and manufacturing sectors, increased from $11 \%$ to $41 \%$, while that of the tertiary sector remained constant at $33 \%$ [31]. These shifts in the structure of the economy show that Bhutan is gradually moving towards a market based modern economy from a traditional agrarian and forestry-based economy.

Over the past decades, Bhutan exhibited an average annual GDP growth rate of $7.6 \%$ that led to a steady increase in per capita GDP from US\$834 in 2003 to US\$2897 in 2016 [32], crossing the threshold for a low income country in 2014 as per the World Bank's criteria, paving the way for a formal graduation to a middle income country by 2021. Paradoxically, Bhutan also went through an economic downturn in 2013 with GDP growth dipping to $2.14 \%$, which fortunately regained to $8 \%$ in 2016 [32]. Imports of goods and services accounted for $53 \%$ of the GDP clearly showing that Bhutan is an import driven economy. Furthermore, the external debt as a percentage of GDP rose from $62 \%$ in 2008 to $101 \%$ in 2016 [32].

The growth trajectory in GDP projected by the Asian Development Bank [33] seems to be very positive ranging from $6.6 \%, 6.8 \%$ to $7.4 \%$ depending on three alternative scenarios to 2030 . This would suggest that the socio-environmentally oriented development philosophy of the GNH outlined below, has not hindered economic development, yet. The imperative of economic growth in an emerging nation like Bhutan means that the nation is always going to enable this to continue so that economic opportunities such as employment and services such as health and education can be provided at a middle economy level. The question is can such integrated development continue as suggested by the GNH? And now there is a new global priority of reducing greenhouse gases so the question also is whether Bhutan can continue its growth into the future as the world attempts radical constraints on greenhouse gases? We discuss the possibilities in Section 6.

\subsection{Greenhouse Gas}

The increasing concentration of greenhouse gases (GHG) that triggers climate change is mentioned as one of the three global challenges in the 21st century [30]. The 5th Assessment Report (AR5) from the IPCC [34] demonstrated unequivocally that the climate is warming, humans have been contributing to the change, and that this change will bring about a range of impacts on cities, countries, and society. Climate change as a threat to socio-economic development is felt deep inside Bhutan, a tiny nation with net carbon sink and sparsely populated [27], therefore contributing little to climate change. For example, past incidences of glacier lake outburst floods (GLOF) have caused loss of human lives, damage to properties and destruction of cultivated agricultural land and were attributed to climate change $[27,35]$.

In order to limit temperatures to $2{ }^{\circ} \mathrm{C}$, or preferably $1.5^{\circ} \mathrm{C}$, significant cuts in carbon emissions are required from all countries [34]. Currently, only nine countries around the world (New Zealand (New Zealand had abandoned its carbon neutral programmes in 2009 [36]), Norway, Costa Rica, Vatican City, Iceland, Maldives, Monaco, Ethiopia and Bhutan) have taken the challenge seriously enough to pledge to become carbon neutral [37]. These nine countries are diverse in geographical size, are at different levels of economic development and are spread around the globe, suggesting that a carbon neutral pathway is possible for any nation state. Encouragingly during the 22nd session of the 
Conference of Parties (COP 22) at Marrakech, the number of nations that pledged for carbon neutrality had increased to 22. While it is beyond the scope of this paper to compare these countries in terms of their carbon neutral aspirations and/or their implementation plans, it is interesting to note that only one country, Bhutan, has successfully achieved this status [27,35]. Bhutan now faces the particular challenge of maintaining carbon neutrality while it develops its economy from a low base. What will it take for Bhutan to continue carbon neutral development as it graduates to a middle income country?

Carbon neutrality is described in various ways $[38,39]$. The broadly accepted intention is to balance the carbon in the atmosphere from the inputs and outputs of a product or service, or in Bhutan's case, the whole economy. The process generally requires the measurement, reduction, and finally offsetting of emissions [38]. From a policy viewpoint, Birchall [36] considers carbon neutrality as an extension of long term climate policy and GHG mitigation strategies. At the national level, there is also no universal definition or framework for carbon neutrality, and many of the countries that have pledged carbon neutrality have not clearly defined it, although in some cases broader strategies for achieving it have been outlined.

In this paper, we define Carbon Neutral development in the context of Bhutan as a socio-economic development pathway with net zero carbon emissions at a national level. Similar to earlier definition, this can include the use of carbon sinks (e.g., growing trees) within the geographical boundary of the country, which can be used to offset national emissions. Forest cover, as outlined in the declaration of the Royal Government of Bhutan [27], is at the heart of Bhutan's carbon neutral strategy and the key to Bhutan achieving its carbon neutral status. As early as 1974, Bhutan first instituted a minimum forest cover policy target of $60 \%$ (RGoB 2011), and this is now a statutory requirement enshrined in the Constitution of Bhutan. Besides the stringent policy outlined above, the strong forest conservation approach in Bhutan can also be attributed to its low population and difficult accessibility due to its rugged terrain. The latest National Forestry Inventory of Bhutan indicates a forest cover of $71 \%$ [40]. The forest cover with a sequestration capacity of 6300-kilotons can be balanced against actual GHG emission of 2200-kilotons in the year 2013 [35]. However, the question will be whether the sink capacity alone keep Bhutan carbon neutral into the future? Will there be a need for a further emission reduction strategy as it grows into a middle-income country? Will it be in conflict with its broader social goals on happiness?

\subsection{Gross National Happiness}

Gross National Happiness (GNH) was first discussed and adopted by the Fourth King of Bhutan in the 1970s [26,41-43], which is essentially a Buddhist philosophy that "measures the quality of a country in a more holistic way [than GDP] and believes that the beneficial development of human society takes place when material and spiritual development occur side by side to complement and reinforce each other" [44]. In keeping with this, Bhutan has been highly focused on GNH to the extent that its Planning Commission was re-named the GNH Commission $[27,45,46]$. Even the Constitution of Bhutan now directs the State to enhance the conditions for pursuing GNH [47]. To the Bhutanese, GNH represents their version of Sustainable Development [26]. GNH in Bhutan is being upheld as a living alternative development model [48] as well as a model for achieving Sustainable Development [25]. GNH is widely publicized and well known for its novel approach to well-being policy [49-51]. Acknowledging the interest in GNH by countries around the world, Bhutan initiated a UN Resolution in July 2011 and subsequently hosted a high level UN meeting in April 2012 for defining a new economic paradigm as part of the SDG deliberations [52]. The new economic paradigm now notes that sustainability is a pre-condition for such a new economic system.

While some call GNH a deliberate strategy to balance the impact of modernization with the values of Buddhist teachings [45], others call it as an invented tradition [43]. Whatever it is called, the underlying aim of GNH is to provide enabling conditions for happiness through its four concrete pillars, nine domains with 33 indicators as shown in Table 1. The 33 indicators further forms 124 variables (see [44]). Alkire [50] considers that the domains of GNH have intrinsic value and 
are irreducible and non-hierarchical. The 124 variables of GNH are assigned threshold or cut-off values - called 'Sufficiency' (Details on how the sufficiency levels are set are provided in page 22-30 and Appendix 2 and 3 of the 2010 GNH survey report. See Reference [44] Ibid) based on Bhutanese values as well as international and national standards wherever available [44]. How the thresholds are set is based on the socio-cultural and economic conditions of Bhutan. For instance, the threshold for the indicators under the living standard domains are set 50\% above Bhutan's national poverty line and the contribution for social support is set at $10 \%$ of the annual per capita income [44]. As per the GNH index, a person is said to be happy if he/she achieves the sufficiency level in six of the nine domains [44].

Table 1. Components of Gross National Happiness Index. Source: $[44,53]$.

\begin{tabular}{|c|c|c|}
\hline \multicolumn{3}{|c|}{ Gross National Happiness Index } \\
\hline 4 Pillars & 9 Domains & 33 Indicators \\
\hline \multirow{4}{*}{ Preservation of Culture } & Psychological Well-being & $\begin{array}{l}\text { Life satisfaction } \\
\text { Positive emotions } \\
\text { Negative emotions } \\
\text { Spirituality }\end{array}$ \\
\hline & Time Use & $\begin{array}{l}\text { Work } \\
\text { Sleep }\end{array}$ \\
\hline & Community vitality & $\begin{array}{l}\text { Donation (time \& money) } \\
\text { Safety } \\
\text { Community relationship } \\
\text { Family }\end{array}$ \\
\hline & Cultural diversity and resilience & $\begin{array}{l}\text { Zorig chusum skills (artistic skills) } \\
\text { Cultural participation } \\
\text { Speak native language } \\
\text { Driglam Namzha (the Way of Harmony) }\end{array}$ \\
\hline Conservation of Environment & Ecological diversity and resilience & $\begin{array}{l}\text { Responsibility towards environment } \\
\text { Ecological issues } \\
\text { Wildlife damage } \\
\text { Urban Issues }\end{array}$ \\
\hline \multirow{3}{*}{ Economic Development } & Living standards & $\begin{array}{l}\text { Per capita income } \\
\text { Assets } \\
\text { Housing }\end{array}$ \\
\hline & Health & $\begin{array}{l}\text { Self-reported health } \\
\text { Healthy days } \\
\text { Disability } \\
\text { Mental health }\end{array}$ \\
\hline & Education & $\begin{array}{l}\text { Knowledge } \\
\text { Literacy } \\
\text { Schooling } \\
\text { Values }\end{array}$ \\
\hline Good Governance & Good Governance & $\begin{array}{l}\text { Fundamental rights } \\
\text { Governance performance } \\
\text { Political participation } \\
\text { Services }\end{array}$ \\
\hline
\end{tabular}

The Centre for Bhutan Studies carried out a national level GNH survey in 2010 and 2015 to ascertain if the nation was increasing in its 'happiness'. The results demonstrated that the national level of the GNH index increased by 1.8\% [42]. The main findings of the $2015 \mathrm{GNH}$ survey indicate that people living in urban areas were happier than rural residents as farmers were less happy than other occupational groups. Furthermore, the findings [42] attribute the increase in the GNH index to increases in living standard and access to basic amenities, which is not surprising for a low income emerging nation, suggesting the imperative for economic growth (see Section 3.1). Notwithstanding this, the GNH surveys suggest that diverse groups of people, illiterate or educated, rich or poor, 
young or old, urban or rural can be happy according to the GNH index, but as noted above, there are differences in happiness levels.

At a national level, Bhutan is considered a "reasonably equitable and sustainable society" [54] with largely happy people despite the low per capita income. For instance, the Gini Coefficient (A commonly used measure of the degree of income inequality [55]) decreased from 0.468 in 2003 [55] to 0.387 in 2012 [56], the population living below the national poverty line decreased from $32 \%$ in 2004 to $12 \%$ in 2012 [56], life expectancy increased from 47.4 years in 1984 [57] to 68 years in 2013 [58] and the GNH index increased from 0.743 in 2010 to 0.756 in 2015 [42]. In addition, from 1990 to 2015, the percentage of the population using improved drinking water increased from $72 \%$ to $100 \%$ and access to improved sanitation facilities had increased from $19 \%$ to $50 \%$ [58]. Brooks [25] and Zurick [59] also observed that the quality of life of Bhutanese had improved over the decades and highlight progress made by Bhutan in development indicators between 1984 and 1998. The Asian Development Bank (2013) attributes Bhutan's socio-economic progress to investments in social infrastructure and services. Can the country's social progress and happiness continue as Bhutan graduates to a middle-income country and beyond? How will Bhutan's carbon neutral pledge impact its social progress as it strides into the future?

\section{Some Grey Shades about Bhutan and Its GNH}

Notwithstanding this commendable progress, Bhutan's position in some of the indices at a global level were not as remarkable as its own GNH index, which is evident from Table 2. Furthermore, the national debt to GDP ratio steadily increased from 65\% in 2008 to $106 \%$ in 2016 [32]. More than the low values in these indices, Brooks [25] observed that consumerism has crept into Bhutanese society and is a real test of GNH. SDG 12 (ensure sustainable consumption and production patterns) highlights this as a significant global policy issue that must be addressed. This is relevant for Bhutan in particular, as they will need to ensure sustainable production and consumption levels to maintain their carbon neutral status. Furthermore, the GNH principles advocate balancing the material and non-material components of human well-being. Thus Bhutan, like all countries, is affected by economic development opportunities and external constraints. To this end, Hayden [60] suggested that the sufficiency-based GNH paradigm is facing tough pressure from productivist elements, suggesting the growing issues in implementing GNH-based development, particularly in the profit-centric industry activities. Thus, Bhutan is struggling as a small, low-income nation to balance the need for economic growth, the requirement to keep GHG emissions low whilst increasing gross national happiness.

Table 2. Bhutan's score in some of the globally reported indices in 2016. Source: [61-64].

\begin{tabular}{cccc}
\hline S1 \# & Index & Score & Rank \\
\hline 1 & World Happiness index & 5.011 & 97 out of 155 countries \\
2 & Human Development Index & 0.607 & 132 out of 188 countries \\
3 & Press Freedom Index & 58 & 122 out of 199 countries \\
4 & Corruption Perception Index & 65 & 27 out of 176 countries \\
\hline
\end{tabular}

Given that no single framework can be called a fit-all-type development framework, GNH has its own limitations. For instance, many doubt the replicability of the GNH concepts to other nations and societies [43,59,65]. Giannetti, Agostinho, Almeida and Huisingh [65] consider GNH as an overly ambitious index that is entirely dependent on subjective survey data that are vulnerable to political manipulation. The GNH analysis which relies heavily on survey data was pointed out as a gap in the methodology [66]. GNH is operationalized in Bhutan through periodic surveys and is seen as a policy screening tool but it does not have explicit indicators about energy and climate change so it will always be a disconnect from the SDGs and the Paris Agreement to which they are totally committed. Ura [54] acknowledges that GNH is not measuring ecological wealth, despite incorporating several environmental related variables. Human-wildlife conflicts, which are being experienced by many 
Bhutanese farmers, are attributed to the conservation policy which arises from the environmental pillar of the GNH [54,67]. All these issues suggest that there are limitations on the supposedly holistic framework of the GNH.

\section{GNH and the SDG Mix}

Agenda 2030 highlights the need for a holistic development paradigm that embodies health, well-being, ecosystem management, urban sustainability, and governance, which underscores the fact that human development is multidimensional, beyond GDP. This is supported by abundant literature that highlights the shortcomings of GDP as a measure of societal progress $[41,65,68-70]$. The SDGs are now recognized as a political expression for achieving sustainable development at the global scale and many scientists argue that nexus thinking (A nexus approach is a system-wide approach recognizing inherent interdependencies of different sectors) will provide a governance heuristic to implement and achieve the SDGs [71]. This is suggesting a fundamental restructuring of the prevalent socio-economic system which is underpinned by classical growth-centered economic theory, into a paradigm that is more equitable through pro-poor goals as reflected in SDG 1 (end poverty), SDG 2 (end hunger), SDG 3 (health), SDG 4 (inclusive and equitable education), SDG 6 (sanitation and water management), SDG 7 (access to modern energy), SDG 8 (inclusive and sustainable economic growth) and SDG 10 (reduce inequality).

Since the adoption of the SDGs, nations around the world started assessing the alignment of their existing programs and policies in relation to the SDGs [72]. For Bhutan, a joint assessment by the UNDP and GNHC revealed that 134 out of 169 SDG targets were prioritized in the present 11th five-year plan, which suggests an excellent starting point for Bhutan to implement the SDGs. Wangmo [73] attributes Bhutan's readiness to achieve the SDGs to the prevailing pursuit of their GNH development concept.

The starting point for any principle contains assumptions and values [74]. At the heart of GNH lies the interdependency concept of the Buddhist philosophy-the cause and effect, the so-called the doctrine of 'karma' $[49,67]$ and it is based on the notion of sufficiency $[44,54,60]$. Thus GNH recognizes interconnectedness, perhaps the essence of sustainability which demands integration of all elements of the development sphere currently being referred to as the triple bottom line, which for Bhutan means the three G's-GNH, GDP, and GHG. Schroeder and Schroeder [75] commends GNH as a model that links happiness to the three dimensions of sustainability. Helne and Hervilami [76] argue for human dependency on the planetary ecosystem and have proposed a 'relational approach' to understand the linkages, which suggests a similar philosophical approach to GNH. Helliwell and Wang [77] argue that a happiness indicator is the most democratic of the well-being measures which provides broader possible ways of making a better world. Giannetti, Agostinho, Almeida and Huisingh [65] suggest GNH to be a powerful communication tool for measuring societal progress towards a paradigm shift away from just GDP. Thus, the underlying values in the GNH have quite considerable support but there are other questions as to whether it can measure meaningfully to provide policy guidance as the SDGs have been created to do.

The nine domains of GNH are interconnected and they are not mutually exclusive [44], which resonates with the indivisibility of the 17 SDGs [3]. The nine domains of GNH and the 17 SDGs illustrates multidimensionality of human development and explicitly contains social, economic and environmental dimensions of sustainability, albeit to a varying degree and specificities (A more thorough comparison would be a useful exercise and provide valuable future research, which remains outside the scope of this paper). The 'sufficiency' concept underpins the threshold settings for components of the GNH (to calculate the GNH index), which informs policy decisions in Bhutan. These threshold values reflect the limits principle of sustainability (see Section 2). Sufficiency in one domain has an inherent tendency to enable other domains according to Alkire [50]. For example, a healthy individual would be expected to have higher life satisfaction. The health domain of GNH integrates well with that represented under SDG 3. Since good governance is critical for the success 
of any system [78], the 'Governance' domain of GNH intend to address the role of State to provide an enabling environment for growth of societal happiness. Environmental conservation forms one of the four pillars of GNH. Similarly, the SDGs are rich in environmental dimensions from sustainable management of terrestrial and marine ecosystems to clean energy and climate action and even mentions the importance of people living in harmony with nature. Thus, both GNH and the SDGs are framed around integration of multiple dimensions surrounding the role of human beings and societies in the natural world.

While the GNH and the SDGs are similar in their attempts at creating a set of policy-based indicators of human and environmental well-being, both have their own shortcomings and thus criticism. Spirituality is considered a vital indicator for Bhutanese well-being [44] and culture forms one of the four pillars of GNH. 'Time Use' in GNH aspires to avoid 'focusing illusion' [79], whereby people work more hours for material comfort, undermining time available for the intangible aspects of human well-being, which also equally matters. Besides cultural priorities, GNH also emphasizes community vitality, perhaps a building block for a vibrant society. Such vital social connections are inadequately reflected in the SDG except for a parsimonious reference under SDG 11 (ensuring safe and inclusive cities and human settlements). In its present form, GNH does not have enough biophysical indicators to measure the nation's ecological wealth [54], a crucial limit which undermines comprehending the ecological limits for a sustainable habitat for mankind.

GNH recognizes economic growth for alleviating physical poverty, but it also emphasizes the need for spiritual development for alleviating inner poverty manifested by anxiety, insecurity, and other similar human frailties. This is consistent with many commentators who suggest that there are diminishing returns for happiness with increased income beyond a certain threshold level [70,80-82]. On the other hand, the SDGs are driven by mainstream economic theory that suggests only economic growth can alleviate physical and mental ill-being. Another point of departure is that the living standard domain of GNH considers both income base and non-income-based wealth. Furthermore, the 'sufficiency level' used as a cut-off threshold for the 33 indicators and 124 variables of the GNH could be seen as a reflection of the Buddhist concept of contentment, which merits an important place in the contemporary discourse of resource depletion and environmental degradation. This is also reflected in the theology of sufficiency or 'enough' elaborated by some in western traditions though such notions have not been translated into an index like the GNH in the western world. The idea underlying these values is that sufficiency instills more sustainable consumption and production behavior, which is clearly captured under SDG 12. Perhaps the Bhutanese catchphrase 'to know the limit is wise; even too much of mother's milk is poisonous' (Translated into English as understood by the lead author from the original phrase that is in Dzongkha, the Bhutanese language) seems to align with assigning sufficiency level in calculating the GNH index.

The recognition of spiritual development, cultural promotion, emotional balance and time balance are perhaps the points of departure of GNH from the SDGs. Verma [48] criticizes SDGs for failing to break away from the prevailing mainstream development approach, which is seen as a point of departure for GNH. Giannetti, Agostinho, Almeida and Huisingh [65] suggests GNH is a paradigm shift away from GDP-only approaches to the future and is a shift of consciousness away from relentless consumerism [49]. But what about the need for clear planetary limits and policy action?

\section{Carbon Neutrality Is a Growing Driver}

On declaring its intention to remain carbon neutral, Bhutan expressed that "there is no need greater than keeping our planet safe for life to continue" [83], which resonates with the broader vision of Sustainable Development [1]. In a carbon-constrained world, keeping the planet safe invariably demands stabilizing GHG emission levels to hold down temperature rise below $1.5^{\circ} \mathrm{C}$ [34]. This requires a global transition towards net zero carbon emissions [29]. The IPCC also recognizes the dual relationship between climate change and sustainable development [84]. To this end, a special volume in the Journal of Cleaner Production emphasized how absolute reductions in material and 
emissions are essential for a sustainable society [85]. However, such a policy can never be separated from other needs and thus the issues discussed next are how to ensure climate policies can be integrated with GNH and GDP commitments.

Climate change is recognized as a threat to socio-economic development which has a bearing on human well-being but also reducing carbon emissions is sometimes seen as a threat to socio-economic development. Bhutan's goal in their climate change policy is to ensure all three are achieved at the same time. In this way, carbon-neutral development in Bhutan complements the holistic vision of the GNH paradigm, which mixes with the SDGs as demonstrated in Section 5, and at the same time to create GDP to enable the achievement of all the goals together. GDP is thus never seen as a single goal dominating all others but something that can facilitate the achievement of GNH and GHG goals as well as opportunities for jobs and incomes to grow. Reducing GHG is a target area of growth and development to manage global public goods and to keep within planetary boundaries as a strong sustainability strategy [74].

With regard to the plausible relationship between carbon emissions (i.e., central to carbon neutrality) and human well-being, using data from 20 countries fulfilling the criteria of the Goldemberg's Corner [86] domain, Lamb [87] demonstrated that human well-being can be delivered at extremely low levels of energy consumption and carbon emissions; this implies the possible role of a well-being framework in climate change policy as Bhutan has constructed. Bhutan's pledge to remain carbon neutral conforms to the GNH pillar of pursuing environmental conservation, which has remained a key aspect of the development policies of Bhutan. Carbon neutral development requires a reduction in carbon emissions through reduced consumption, as well as through carbon sinks. Low carbon development can be seen as an essential step towards delivering the aims of poverty alleviation, economic growth and enhanced well-being [88], demonstrating strong linkages with the SDGs. Urban [89] argues that low carbon development can be an opportunity for low income countries to pursue pro-poor development and Mulugetta and Urban [88] states that low carbon development is rooted in sustainable development. Kumi, et al. [90] recommend the merit of a pro-poor growth approach to achieving the SDGs. Such concerns can be seen explicitly stated under SDG 1.b which calls for action to: "Create sound policy frameworks at the national, regional and international levels, based on pro-poor and gender-sensitive development strategies, to support accelerated investment in poverty eradication actions" [3]. This is precisely the aspiration of a low-income country like Bhutan to remain carbon neutral while operationalizing the GNH development paradigm. Bhutan's 2011 National Human Development Report [28] recognizes the need to delink carbon emissions from economic and human development. Schroeder and Schroeder [75] therefore hail GNH as a model that attempts to decouple the economy from environmental pressure. Therefore, pursuing carbon neutral development can benefit the GNH vision. Such integration has strong linkages to the SDGs.

Andersson, Nässén, Larsson, and Holmberg [81] showed the possibility of low carbon living without undermining subjective well-being at household level. However, well-being does not appear to increase in a linear fashion along with income, especially when targeting carbon neutrality. Pledging to remain carbon neutral clearly indicates climate change action, which addresses SDG 13. Thus, enhancing human well-being (GNH) and reducing GHG emissions (Carbon Neutral) is possible, while directly linking to the larger goals of sustainable development.

\section{Conclusions}

Sustainable development has been growing in practice and theory. The three theoretical areas that have developed-Ecological Economics, Sustainability Science, and Sustainability Transitions-have not yet led to a clear link with professional practice and national policy setting. However, they require principles such as inter-generational equity and living within the bio-capacity of the biosphere to modify how economic development is pursued. This paper has attempted to see whether the approach adopted by Bhutan can help provide a better link between the theory and practice, especially in emerging countries where the economic growth imperative is so strong. 
Bhutan has suggested that the GNH approach with its clear set of indicators is perhaps a simpler way of understanding sustainability and the 17 SDGs.

GNH-based development aspires to balance material well-being and cultural or spiritual aspects of well-being, which is increasingly being recognized as a necessity for economic development. However, the imperative of economic growth in an emerging economy and the new imperative of rapidly reducing greenhouse gas emissions, are starker drivers in Bhutan and most other countries. Hence, to make sustainable development a truly meaningful and practical set of guidelines for a nation, it is necessary to bring GNH, GDP, and GHG together. Thus, this paper has concluded that 'integrating the three G's' approach to sustainable development may indeed be a better way to approach the future.

Drawing insights from the literature and demonstrating plausible linkages between the GNH and the SDGs, this study has shown that most of the components of the SDGs and the GNH can be linked to some degree, indicating that the GNH paradigm can indeed contribute to achieving the SDGs. However, further examination of the specific goals and indicators under each of the key categories highlighted some gaps and missing links. This presents an opportunity for each of the other two G's, GHG and GDP, to help inform GNH and for the three together to provide direction for how humanity strives towards creating a productive, sustainable and happy society.

Pursuing carbon neutrality complements the GNH development paradigm by specifically targeting carbon emissions, thus addressing climate change, a key element of the SDGs. And bringing the GDP goal into clear focus and then integrating it into the GNH and GHG goals also fills out the idea of sustainable development in a way that is both better in terms of theory and most of all in practice.

This paper has therefore shown that Bhutan, following its GNH development philosophy, along with its carbon neutral declaration, and its GDP commitments, will find the challenge of meeting the SDGs easier than other developing nations with fewer guidelines and targets for holistic socio-economic development. The Bhutan model of fully integrating GNH, GDP and GHG suggests a way forward for Bhutan to achieve the SDGs including the difficult climate change goal, whilst continuing to enable GDP to grow. This combination and integration may also suggest a model for other nations wanting to find a simpler way of framing the 17 SDGs into a coherent set of policies.

We believe that Bhutan provides a showcase for happiness and prosperity within a carbon neutral budget, and thus, a constructive role model for other countries seeking alignment with the new universal sustainable development goals and the Paris Agreement.

Author Contributions: Conceptualization, D.Y. and P.N.; Methodology, D.Y. and P.N.; Writing-Original Draft Preparation, D.Y., P.N., V.R. and P.D.; Writing-Review \& Editing, D.Y., P.N. and V.R.

Acknowledgments: The lead author would like to thank the Government of Australia for providing the Research Training Programme (RTP) scholarship and Curtin University for the Curtin Research top up Scholarship (CRS). The authors deeply thank the four reviewers for their constructive feedback, which helped in substantively improving the paper.

Conflicts of Interest: The authors declare no conflict of interest. The funding sponsors had no role in the design of the study; in the collection, analyses, or interpretation of data; in the writing of the manuscript, and in the decision to publish the results.

\section{References}

1. World Commission on Environment and Development (WCSD). Report of the World Commission on Environment and Development: Our Common Future; World Commission on Environment and Development: Oxford, UK, 1987.

2. United Nations. Report of the United Nations Conference on Sustainable Development; The United Nations: New York, NY, USA, 2012.

3. United Nations. Transforming Our World: The 2030 Agenda for Sustainable Development; The United Nations: New York, NY, USA, 2015.

4. UN Framework Convention on Climate Change. Decisions Adopted by the Conference of the Parties Session 21; United Nations Framework Convention on Climate Change: Paris, France, 2016.

5. Mascarelli, A. Sustainability: Environmental puzzle solvers. Nature 2013, 494, 507-509. [CrossRef] [PubMed] 
6. Newman, P.; Rowe, M. Hope for the Future: The Western Australian State Sustainability Strategy; Department of the Premier and Cabinet: Perth, WA, USA, 2003.

7. Newman, P.; Kenworthy, J. Sustainability and Cities: Overcoming Automobile Dependence; Island Press: Washington, DC, USA, 1999.

8. Quental, N.; Lourenço, J.M.; da Silva, F.N. Sustainability: Characteristics and scientific roots. Environ. Dev. Sustain. 2011, 13, 257-276. [CrossRef]

9. Daly, H.E. Beyond Growth: The Economics of Sustainable Development; Beacon Press: Boston, MA, USA, 1996.

10. Costanza, R. Ecological Economics: The Science and Management of Sustainability; Columbia University Press: New York, NY, USA, 1991.

11. Schellnhuber, H.J.; Crutzen, P.J.; Clark, W.C.; Hunt, J. Earth system analysis for sustainability. Environ. Sci. Policy Sustain. Dev. 2005, 47, 10-25. [CrossRef]

12. Kates, R.; Clark, W.; Corell, R.; Hall, J.; Jaeger, C.; Lowe, I.; McCarthy, J. Sustainability science. Science 2001, 292, 641-642. [CrossRef] [PubMed]

13. Kates, R.W. What kind of a science is sustainability science? Proc. Natl. Acad. Sci. USA 2011, 108, 19449-19450. [CrossRef] [PubMed]

14. National Research Council. Our Common Journey: A Transition toward Sustainability; National Academy Press: Washington, DC, USA, 1999.

15. Geels, F.W. Technological transitions as evolutionary reconfiguration processes: A multi-level perspective and a case-study. Res. Policy 2002, 31, 1257-1274. [CrossRef]

16. Geels, F.W.; Sovacool, B.K.; Schwanen, T.; Sorrell, S. Sociotechnical transitions for deep decarbonization. Science 2017, 357, 1242-1244. [CrossRef] [PubMed]

17. Ostrom, E. Frameworks and theories of environmental change. Glob. Environ. Chang. 2008, 18, $249-252$. [CrossRef]

18. Cumming, G.S. Theoretical frameworks for the analysis of social-ecological systems. In Social-Ecological Systems in Transition; Sakai, S., Umetsu, C., Eds.; Springer: Tokyo, Japan, 2014; pp. 3-24.

19. Orach, K.; Schlüter, M. Uncovering the political dimension of social-ecological systems: Contributions from policy process frameworks. Glob. Environ. Chang. 2016, 40, 13-25. [CrossRef]

20. Holling, C.S. Understanding the complexity of economic, ecological, and social systems. Ecosystems 2001, 4, 390-405. [CrossRef]

21. Markard, J.; Raven, R.; Truffer, B. Sustainability transitions: An emerging field of research and its prospects. Res. Policy 2012, 41, 955-967. [CrossRef]

22. Hacking, T.; Guthrie, P. A framework for clarifying the meaning of triple bottom-line, integrated, and sustainability assessment. Environ. Impact Assess. Rev. 2008, 28, 73-89. [CrossRef]

23. Halog, A.; Manik, Y. Advancing integrated systems modelling framework for life cycle sustainability assessment. Sustainability 2011, 3, 469-499. [CrossRef]

24. Royal Government of Bhutan. Bhutan 2020 (Part II): A Vision for Peace, Prosperity and Happiness; Royal Government of Bhutan: Thimphu, Bhutan, 1999.

25. Brooks, J.S. Avoiding the limits to growth: Gross national happiness in Bhutan as a model for sustainable development. Sustainability 2013, 5, 3640-3664. [CrossRef]

26. Royal Government of Bhutan (RGoB). Bhutan: In Pursuit of Sustainable Development-National Report for the United Nations Conference on Sustainable Development 2012; Royal Government of Bhutan: Thimphu, Bhutan, 2012.

27. National Environment Commission (NEC). Second National Communication to the UNFCCC; National Environment Commission: Thimphu, Bhutan, 2011.

28. Gross National Happiness Commission (GNHC). Bhutan National Human Development Report-Sustaining Progress: Rising to the Climate Challenge; Gross National Happiness Commission: Thimphu, Bhutan, 2011.

29. Rogelj, J.; Schaeffer, M.; Meinshausen, M.; Knutti, R.; Alcamo, J.; Riahi, K.; Hare, W. Zero emission targets as long-term global goals for climate protection. Environ. Res. Lett. 2015, 10, 105007. [CrossRef]

30. Newton, P.; Newman, P. Critical connections: The role of the built environment sector in delivering green cities and a green economy. Sustainability 2015, 7, 9417-9443. [CrossRef]

31. National Statistical Bureau. Bhutan National Accounts Statistics; National Statistical Bureau: Thimphu, Bhutan, 2004.

32. National Statistical Bureau. National Accounts Statistics; National Statistical Bureau: Thimphu, Bhutan, 2017. 
33. Mitra, S.; Carrington, S.; Baluga, A. Unlocking Bhutan's Potential: Measuring Potential Output for the Small, Landlocked Himalayan Kingdom of Bhutan; Asian Development Bank: Manila, Philippines, 2014.

34. Intergovernmental Panel on Climate Change (IPCC). Climate Change 2014: Synthesis Report. Contribution of Working Groups I, II and III to the Fifth Assessment Report of the Intergovernmental Panel on Climate Change; Core Writing Team, Pachauri, R.K., Meyer, L.A., Eds.; Intergovernmental Panel on Climate Change (IPCC): Geneva, Switzerland, 2014.

35. Royal Government of Bhutan (RGoB). Communication of the INDC of the Kingdom of Bhutan; National Environment Commission: Thimphu, Bhutan, 2015.

36. Birchall, J. New Zealand's abandonment of the carbon neutral public service programme. Clim. Policy 2014, 14, 525-535. [CrossRef]

37. Flagg, J.A. Aiming for zero: What makes nations adopt carbon neutral pledges? Environ. Sociol. 2015, 202-212. [CrossRef]

38. Rauland, V.; Newman, P. The rise of carbon neutrality. In Decarbonising Cities: Mainstreaming Low Carbon Urban Development; Springer International Publishing: Cham, Switzerland, 2015; pp. 95-112.

39. Murray, J.; Dey, C. The carbon neutral free for all. Int. J. Greenh. Gas Control 2008, 3, 237-248. [CrossRef]

40. Ministry of Agriculture and Forestry. National Forest Inventory Report: Stocktaking Nation's Forest Resources; Ministry of Agriculture and Forestry: Thimphu, Bhutan, 2017; Volume 1.

41. Royal Govenment of Bhutan. Bhutan 2020 (Part I): A Vision for Peace, Prosperity and Happiness; Royal Govenment of Bhutan: Thimphu, Bhutan, 1999.

42. Centre for Bhutan Studies. A Compass towards a Just and Harmonious Society: 2015 GNH Survey Report; Centre for Bhutan Studies \& GNH Research: Thimphu, Bhutan, 2016.

43. Munro, L.T. Where did Bhutan's gross national happiness come from? The origins of an invented tradition. Asian Aff. 2016, 47, 71-92. [CrossRef]

44. Centre for Bhutan Studies. An Extensive Analysis of GNH Index; Ura, K., Alkire, S., Zangmo, T., Wangdi, K., Eds.; Centre for Bhutan Studies: Thimphu, Bhutan, 2012.

45. Givel, M.S. Gross national happiness in Bhutan: Political institutions and implementation. Asian Aff. 2015, 46, 102-117. [CrossRef]

46. Stoerk, T.; Dorji, L. A Compendium of Gross National Happiness (GNH) Statistics; National Statistical Bereau: Thimphu, Bhutan, 2014.

47. Royal Government of Bhutan. The Constitution of the Kingdom of Bhutan; Royal Government of Bhutan: Thimphu, Bhutan, 2008.

48. Verma, R. SDGs: Value-Added for GNH? Challenges and Innovations of a Development Alternative from a Socio-Cultural Lens. Available online: http:/ / drukjournal.bt/sdgs-value-added-for-gnh-challenges-andinnovations-of-a-development-alternative-from-a-socio-cultural-lens/ (accessed on 13 May 2018).

49. Allison, E. Gross national happiness. In The Berkshire Encyclopedia of Sustainability: Measurements, Indicators, and Research Methods for Sustainability; Berkshire Publishing Group: Great Barrington, MA, USA, 2012; pp. 180-184.

50. Alkire, S. Well-Being, Happiness, and Public Policy; Centre for Bhutan Studies \& GNH Research: Thimphu, Bhutan, 2015.

51. Pennock, M.; Ura, K. Gross national happiness as a framework for health impact assessment. Environ. Impact Assess. Rev. 2011, 31, 61-65. [CrossRef]

52. Royal Government of Bhutan. The Report of the High-Level Meeting on Wellbeing and Happiness: Defining a New Economic Paradigm; The Permanent Mission of the Kingdom of Bhutan to the United Nations: New York, NY, USA, 2012; p. 164.

53. Thinley, J.Y. What does gross national happiness (GNH) mean? In Proceedings of the Rethinking Development: 2nd International Conference on GNH, Halifax, NS, Canada, 20-24 June 2005.

54. Ura, K. The Experience of Gross National Happiness as Development Framework; Asian Development Bank: Manila, Philippines, 2015.

55. National Statistical Bureau. Bhutan Living Standard Survey Report for 2003; National Statistical Bureau of Bhutan: Thimphu, Bhutan, 2003.

56. National Statistics Bureau (NSB); Asian Development Bank (ADB). Bhutan Living Standards Survey 2012 Report; National Statistics Bureau and Asian Development Bank: Thimphu, Bhutan, 2013. 
57. Royal Government of Bhutan. Bhutan National Human Development Report 2000: Gross National Happiness and Human Development-Searching for Common Ground; Planning Commission of Bhutan: Thimphu, Bhutan, 2000.

58. Asian Development Bank. Part II-Millennium development goals trends and tables. In Key Indicators for Asia and the Pacific 2015; Asian Development Bank: Mandaluyong, Philippines, 2015; pp. 109-190.

59. Zurick, D. Gross national happiness and environmental status in Bhutan. Geogr. Rev. 2007, 657-681. [CrossRef]

60. Hayden, A. Bhutan: Blazing a trail to a Postgrowth future? Or stepping on the treadmill of production? J. Environ. Dev. 2015, 24, 161-186. [CrossRef]

61. Freedom House. Freedom of the Press 2017; Freedom House: Washington, DC, USA, 2017.

62. Helliwell, J.; Layard, R.; Sachs, J. World Happiness Report 2017; Sustainable Development Solutions Network: New York, NY, USA, 2017.

63. Transperency International. Corruption Perception Index 2016; Transperency International: Berlin, Germany, 2016.

64. United Nations Development Programme. Bhutan: Briefing Note for Countries on the 2016 Human Development Report; United Nations Development Programme: New York, NY, USA, 2016.

65. Giannetti, B.F.; Agostinho, F.; Almeida, C.M.V.B.; Huisingh, D. A review of limitations of GDP and alternative indices to monitor human wellbeing and to manage eco-system functionality. J. Clean. Prod. 2015, 87, 11-25. [CrossRef]

66. Verma, R.; Ura, K. Gender differences in Gross National Happiness in Bhutan: Abridged Analysis of GNH Surveys. In Proceedings of the 6th International Conference on Gross National Happiness, Paro, Bhutan, 4-6 November 2015; Ura, K., Penjore, D., Eds.; Centre for Bhutan Studies \& GNH: Thimphu, Bhutan, 2017; pp. 197-247.

67. Rinzin, C. On the Middle Path—The Social Basis for Sustainable Development in Bhutan; Netherlands Geographical Studies 352: Utrecht, The Netherlands, 2006; p. 204.

68. Kubiszewski, I.; Costanza, R.; Franco, C.; Lawn, P.; Talberth, J.; Jackson, T.; Aylmer, C. Beyond GDP: Measuring and achieving global genuine progress. Ecol. Econ. 2013, 93, 57-68. [CrossRef]

69. Knight, K.W.; Rosa, E.A. The environmental efficiency of well-being: A cross-national analysis. Soc. Sci. Res. 2011, 40, 931-949. [CrossRef]

70. Stiglitz, J.E.; Sen, A.; Fitoussi, J.-P. Report by the Commission on the Measurement of Economic Performance and Social Progress; Commission on the Measurement of Economic Performance and Social Progress: Paris, France, 2009.

71. Müller, A.; Janetschek, H.; Weigelt, J. Towards a governance heuristic for sustainable development. Curr. Opin. Environ. Sustain. 2015, 15, 49-56. [CrossRef]

72. Lucas, P.; Ludwig, K.; Kok, M.; Kruitwagen, S. Sustainable Development Goals in The Netherlands-Building Blocks for Environmental Policy for 2030; PBL Netherlands Environmental Assessment Agency: The Hague, The Netherlands, 2016.

73. Wangmo, T. Starting strong on the SDGs in Asia: Readiness in Bhutan. In IGES Discussion Paper; Institute for Global Environmental Strategies: Kanagawa, Japan, 2016.

74. Nilsson, M.; Lucas, P.; Yoshida, T. Towards an integrated framework for SDGs: Ultimate and enabling goals for the case of energy. Sustainability 2013, 5, 4124-4151. [CrossRef]

75. Schroeder, R.; Schroeder, K. Happy environments: Bhutan, interdependence and the west. Sustainability 2014, 6, 3521-3533. [CrossRef]

76. Helne, T.; Hirvilammi, T. Wellbeing and sustainability: A relational approach. Sustain. Dev. 2015, 23, 167-175. [CrossRef]

77. Helliwell, J.F.; Wang, S. The state of world happiness. In World Happiness Report; Helliwell, J., layard, R., Sachs, J., Eds.; The Earth Institute: New York, NY, USA, 2012.

78. Waage, J.; Yap, C.; Bell, S.; Levy, C.; Mace, G.; Pegram, T.; Unterhalter, E.; Dasandi, N.; Hudson, D.; Kock, R.; et al. Governing sustainable development goals: Interactions, infrastructures, and institutions. In Thinking beyond Sectors for Sustainable Development; Waage, J., Yap, C., Eds.; Ubiquity Press Ltd.: London, UK, 2015; pp. 79-88.

79. Galay, K. Patterns of Time Use and Happiness in Bhutan: Is There a Relationship between the Two? Institute of Developing Economies, External Trade Organization: Tokyo, Japan, 2007.

80. Jackson, T. Prosperity without Growth?-The Transition to a Sustainable Economy; Sustainable Development Commission: London, UK, 2009; p. 136. 
81. Andersson, D.; Nässén, J.; Larsson, J.; Holmberg, J. Greenhouse gas emissions and subjective well-being: An analysis of Swedish households. Ecol. Econ. 2014, 102, 75-82. [CrossRef]

82. Kahneman, D.; Deaton, A. High income improves evaluation of life but not emotional well-being. Proc. Natl. Acad. Sci. USA 2010, 107, 16489-16493. [CrossRef] [PubMed]

83. Royal Govenment of Bhutan. Regarding the Copenhagen Accord of December 2010; Royal Govenment of Bhutan: Thimphu, Bhutan, 2010.

84. Halsnæs, K.; Shukla, P.; Ahuja, D.; Akumu, G.; Beale, R.; Edmonds, J.; Gollier, C.; Grübler, A.; Duong, M.H.; Markandya, A.; et al. Framing issues. In Climate Change 2007: Mitigation. Contribution of Working Group III to the Fourth Assessment Report of the Intergovernmental Panel on Climate Change; Intergovernmental Panel on Climate Change: New York, NY, USA, 2007.

85. Akenji, L.; Bengtsson, M.; Bleischwitz, R.; Tukker, A.; Schandl, H. Ossified materialism: Introduction to the special volume on absolute reductions in materials throughput and emissions. J. Clean. Prod. 2016, 132, 1-12. [CrossRef]

86. Wangchuk, S.; Siebert, S.; Belsky, J. Fuelwood use and availability in Bhutan: Implications for national policy and local forest management. Hum. Ecol. 2013, 42, 127-135. [CrossRef]

87. Lamb, W.F. Which countries avoid carbon-intensive development? J. Clean. Prod. 2016, 131, 523-533. [CrossRef]

88. Mulugetta, Y.; Urban, F. Deliberating on low carbon development. Energy Policy 2010, 38, 7546-7549. [CrossRef]

89. Urban, F. The MDGs and beyond: Can low carbon development be pro-poor? Inst. Dev. Stud. Bull. 2010, 41, 92-99. [CrossRef]

90. Kumi, E.; Arhin, A.A.; Yeboah, T. Can post-2015 sustainable development goals survive neoliberalism? A critical examination of the sustainable development-neoliberalism nexus in developing countries. Environ. Dev. Sustain. 2014, 16, 539-554. [CrossRef] 